\title{
Cryoglobulin Volume to Serum Volume Ratio Measurement
}

National Cancer Institute

\section{Source}

National Cancer Institute. Cryoglobulin Volume to Serum Volume Ratio Measurement. NCI Thesaurus. Code C147325.

The determination of the ratio of cryoglobulin volume compared to serum volume present in a sample. The measurement may be expressed as a ratio or percentage. 